\title{
A comparative study on placebo and trenaxamic acid for the prophylaxis is of post-partum hemorrhage: a randomised double-blind control study
}

\section{S. Parveen ${ }^{1 *}$, G. Kesava Chandra ${ }^{2}$, K. Ravindra Reddy ${ }^{3}$, A. V. Kavya Sree ${ }^{1}$, M. Varalakshmi ${ }^{1}$, R. Gayathri ${ }^{1}$, V. Bhuvana Chandra ${ }^{1}$, P. Venkata Ramana ${ }^{1}$}

\begin{abstract}
${ }^{1}$ Department of Pharmacy Practice, P. Rami Reddy Memorial College of Pharmacy, Kadapa, Andhra Pradesh, India ${ }^{2}$ Department of Obstetrics and Gynecology, Rajiv Gandhi Institute of Medical Sciences, Kadapa, Andhra Pradesh, India

${ }^{3}$ Principal, P. Rami Reddy Memorial College of Pharmacy, Kadapa, Andhra Pradesh, India
\end{abstract}

Received: 05 December 2018

Accepted: 11 January 2019

\section{*Correspondence:}

Dr. S. Parveen,

E-mail: s.parveenpharmd@gmail.com

Copyright: (C) the author(s), publisher and licensee Medip Academy. This is an open-access article distributed under the terms of the Creative Commons Attribution Non-Commercial License, which permits unrestricted non-commercial use, distribution, and reproduction in any medium, provided the original work is properly cited.

\section{ABSTRACT}

Background: Obstetric haemorrhage accounts for 20-25\% of maternal mortality and morbidity. Anti-fibrinolytics are being widely used in field of surgery. It is also used to reduce heavy menstrual blood loss. The aim of this study was to analyse the effectiveness of TXA in reducing blood loss during normal vaginal delivery.

Methods: The randomized double-blind control study was done in the Labour ward. It was conducted on 100 women undergoing Normal vaginal delivery. They were allocated to either Study or Control group by randomization. TXA was given during the Third stage of delivery in study group in addition to the routine care whereas the control group had routine care alone. Blood loss was measured in both groups by bag method.

Results: The significant of reduction in blood loss calculated from placental delivery to $2 \mathrm{hrs} .141 .9 \mathrm{ml}$ in study group versus $270.4 \mathrm{ml}$ in control group. Among primi patients, the control group average blood loss was $325 \mathrm{ml}$, the study group avg blood loss was $169 \mathrm{ml}$. Among G2 patients, the control group average blood loss was $248.5 \mathrm{ml}$. The study group average blood loss was $128.25 \mathrm{ml}$. Among G3 patients, the control group average blood loss was $203 \mathrm{ml}$, the study group average blood loss was $115 \mathrm{ml}$.

Conclusions: TXA significantly reduced the amount of blood loss during normal vaginal delivery. Thus, TXA can be used safely and effectively in subjects undergoing normal vaginal delivery.

Keywords: Normal vaginal deliveries, Postpartum hemorrhage, Prevention, Randomization, Tranexamic acid, Treatment

\section{INTRODUCTION}

Primary postpartum hemorrhage (PPH) is classically defined as blood loss of $\geq 500 \mathrm{ml}$ in the first 24 hour after delivery. Secondary PPH is defined as abnormal or excessive bleeding from the birth canal between 24 hours and 12 weeks postnatal. It is a major cause of maternal mortality and accounts for about one-quarter of all maternal deaths worldwide. it is the leading cause of maternal death, responsible for $27 \%$ of direct maternal deaths in France for 2007-2009, compared, for example, with $8 \%$ in the UK for 2006-2008, despite their relatively similar overall maternal mortality rates. Prevalence estimates for PPH in the literature vary widely, from $3 \%$ to $15 \%$ of deliveries. The world health organization (WHO) estimates that, of the 5,29,000 maternal deaths 
occurring every year, 136000 or $25.7 \%$ take place in India, where two-thirds of maternal deaths occur after delivery, postpartum hemorrhage being the most commonly reported complication and the leading cause of death $(29.6 \%)$. This diversity is explained partly by the variety of criteria and methods used to define PPH: definitions are based on hematological indicators or on the volume of blood loss, which in turn can be estimated clinically or measured more objectively by, for example, a blood collection bag. ${ }^{1}$ The four Ts to provide a simplistic categorization of the causes of PPH. ${ }^{2}$ Tone: (uterine atony), trauma, tissue, thrombin. Tone is the inability to uterus to contract, trauma is an injury to birth canal, tissue is a retention of tissue from the placenta thrombin is a bleeding disorder. ${ }^{3-5}$

Tranexamic acid (TA), an antifibrinolytic agent, could exert its hemostasis effect via inhibiting the activation of plasminogen to plasmin. ${ }^{6}$ Tranexamic acid (TXA) is used to decrease blood loss in surgery and health conditions associated with increased bleeding. ${ }^{7}$ It works by helping to prevent the breakdown of fibrin and maintenance of blood clots. ${ }^{8}$ This review found that TA was also effective in reducing excessive blood loss, need for additional medical interventions to control bleeding and blood transfusions after a mother gave birth based on studies of mixed quality. During delivery, when the placenta separates from the uterine wall, sequential physiologic and haemostatic changes occur and reduce bleeding, including strong myometrial contractions, increased platelet activity, and a massive release of coagulant factor at the same time fibrinolytic activity increases.

A randomized controlled trial is a type of scientific experiment which aims to reduce bias when testing a new treatment. The people participating in the trial are randomly allocated to either the group receiving the treatment under investigation or to a group receiving standard treatment (or placebo treatment) as the control. Randomization with blinding avoids reporting bias, since no one knows who is treated and who is not and therefore all treatment groups should be treated the same ${ }^{9}$ The aim of this study was to compare the effect of a low dose of TXA (1g) with placebo after vaginal delivery, for the prophylaxis of post-partum hemorrhage.

\section{METHODS}

The study was conducted after obtaining permission from the institutional ethical committee. The patients were enrolled into the study after taking informed consent form from them. This randomized double-blind control study was conducted in Obstetrics and Gynecology Department at Rajiv Gandhi Institute of Medical Sciences, Kadapa for a period of 6 months.

During 6 months of the study period 100 patients were included. The enrolment of patients into study was done on the basis of inclusion and exclusion criteria.

\section{Inclusion criteria}

- The patients who planned normal vaginal delivery (term $\geq 37$ weeks of gestation), patients who are with singleton pregnancy were included.

\section{Exclusion criteria}

- Patients with any other co-morbidities like epilepsy, venous thrombosis, hypertension, patients who were with multiple pregnancy $(>3)$ were excluded.

Patient data collection form, Informed consent form, Patient blood loss measuring bags were used as study materials. Initially authors recruited the third stage of labour patients, and authors divided them into 2 groups i.e. test and standard groups. Both groups were treated with oxytocin and Tranexamic acid was given only to the test group patients, and placebo was given to the standard group of patients blindly. The blood loss was measured for both the groups for 2 hours by using bag method. The outcomes were measured for both the groups simultaneously, suitable alterations and suggestions was given for health-related problems occurred if any.

\section{Statistical analysis}

Statistical analysis by using student paired t-test with IBM SPSS statistics software, version 24 to find out PValue. Average and SD was assessed by using Microsoft 2013 excel data sheet.

\section{RESULTS}

This randomized double-blind control study was conducted for a period of 6 months i.e. August 2017 to January 2018 at Rajiv Gandhi Institute of Medical Sciences, Kadapa.

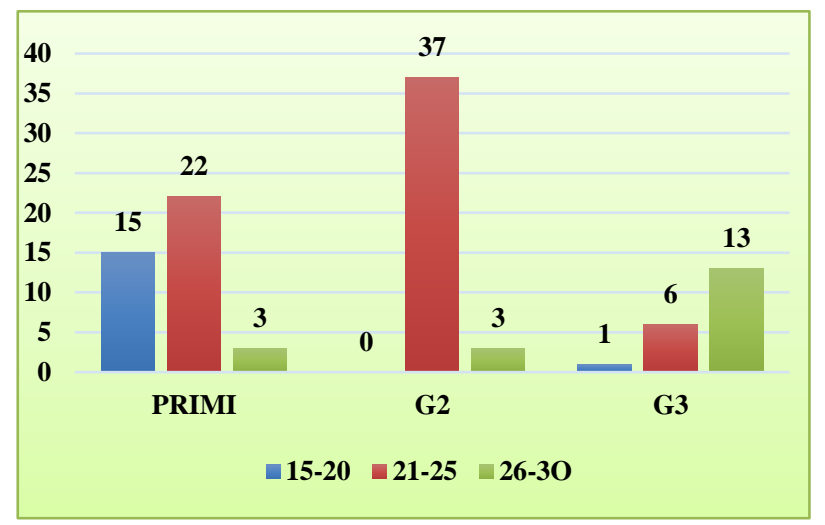

Figure 1: Distribution of patients based on age.

Authors recruited 100 patients in present study among them $16(16 \%)$ patients were in between the age group of 15-20 years and $65(65 \%)$ patients were in between the age group of 21-25 years and 19(19\%) patients were in between the age group of 26-30 years (Figure 1). 
The average mean for placebo patients based on age was 23.08 and the average mean for TXA was 23.2. The total mean for overall patients based on age was 23.14.

\section{Distribution of patients based on blood loss}

Authors recruited 100 patients in present study and among them 10 patients were found to be of below 100 ml blood loss. In that 10 patients, $9(18 \%)$ patients were placebo group $1(2 \%)$ patients were TXA group and 45 patients found to be below $200 \mathrm{ml}$ of blood loss. In that 45 patients $35(70 \%)$ patients were placebo group, 10 (20\%) patients were TXA group and 30 patients found to be below $300 \mathrm{ml}$ of blood loss. In that $6(12 \%)$ patients were placebo group and $24(48 \%)$ patients were TXA and 15 patients found to be below $400 \mathrm{ml}$ of blood loss. In that $0(0 \%)$ placebo group $15(30 \%)$ were TXA (Table1).

Table 1: Blood loss distribution.

\begin{tabular}{|c|c|c|c|c|c|c|c|c|}
\hline \multicolumn{2}{|c|}{ Blood loss (ml) } & \multicolumn{2}{|c|}{ Placebo } & \multicolumn{2}{|l|}{ Percentage } & \multicolumn{2}{|c|}{ TXA } & \multirow[t]{2}{*}{ Percentage } \\
\hline & Primi & G2 & G3 & & Primi & G2 & G3 & \\
\hline $1-100$ & 2 & 4 & 3 & 18 & 0 & 0 & 1 & 2 \\
\hline $101-200$ & 12 & 16 & 7 & 70 & 2 & 6 & 2 & 20 \\
\hline $201-300$ & 6 & 0 & 0 & 12 & 5 & 17 & 2 & 48 \\
\hline $301-400$ & 0 & 0 & 0 & 0 & 13 & 1 & 1 & 30 \\
\hline
\end{tabular}

Table 2: Mode of delivery distribution.

\begin{tabular}{|l|l|l|l|l|l|l|l|l|}
\hline & \multicolumn{4}{c}{ Placebo } & \multicolumn{4}{|c|}{ TXA } \\
\hline & Primi & G2 & G3 & Percentage & Primi & G2 & G3 & Percentage \\
\hline NVD & 6 & 17 & 8 & 62 & 6 & 18 & 10 & 68 \\
\hline NVD with episiotomy & 7 & 2 & 1 & 20 & 13 & 2 & 0 & 30 \\
\hline Abnormal delivery with forceps & 8 & 1 & 0 & 18 & 1 & 0 & 0 & 2 \\
\hline
\end{tabular}

$\mathrm{N}=100(100 \%)$

The average mean for placebo patients based on blood loss is $270.4 \mathrm{ml}$ and the average mean for TXA patients is 141.9 based on blood loss.

\section{Distribution based on mode of delivery}

Authors recruited 100 patients in present study among them 65 patients were with NVD (normal vaginal delivery). Out of which $31(62 \%)$ patients were of placebo group and 34 (68\%) patients were of TXA group, 25 patients were with NVD with episiotomy and in that $10(20 \%)$ patients were of placebo group and $15(30 \%)$ patients were of TXA group. 10 patients were of abnormal labor with forceps and in that $9(18 \%)$ patients were of placebo group and $1(2 \%)$ patients were of TXA group represented in Table 2.

\section{Distribution based on treatment}

Authors had recruited 100 patients in present study. Among them authors had administered placebo to 20 $(40 \%)$ primi patients, $20(40 \%) \mathrm{G} 2$ patients and $10(20 \%)$ G3 patients and authors had administered TXA to 20 (40\%) primi patients, $20(40 \%) \mathrm{G} 2$ patients and $10(20 \%)$ G3 patients represented in Figure 2.

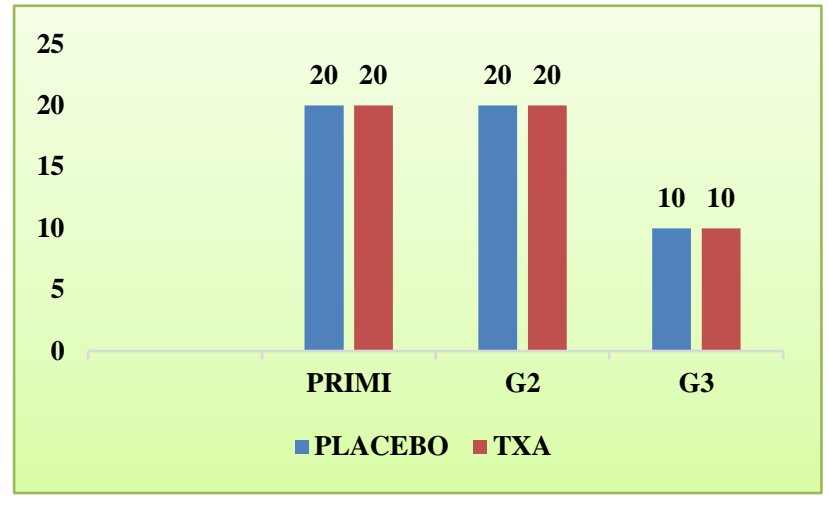

Figure 2: Distribution based on treatment.

\section{Characterization of test group of patients as per present study protocol}

Authors recruited 50 patients and treated with TXA along with oxytocin, in that Gravida 1 Primi group patients were 20 and average blood loss was $169 \mathrm{ml}$, Gravida 2 group patients were 20 and average blood loss was $128.25 \mathrm{ml}$ and Gravida 3 group patients were 10 and avg. blood loss was $115 \mathrm{ml}$. Standard deviation for test group was 44.27 which was shown in Table 3. 
Table 3: Test group patient's characterization.

\begin{tabular}{|l|l|l|l|l|}
\hline $\begin{array}{l}\text { Treatment } \\
\text { given }\end{array}$ & $\begin{array}{l}\text { No. of } \\
\text { patients }\end{array}$ & Primi & $\begin{array}{l}\text { Gravida } \\
2\end{array}$ & $\begin{array}{l}\text { Gravida } \\
3\end{array}$ \\
\hline $\begin{array}{l}\text { Tranexamic } \\
\text { acid }+ \\
\text { oxytocin }\end{array}$ & 50 & 20 & 20 & 10 \\
\hline $\begin{array}{l}\text { Average blood loss } \\
\text { Standard deviation }\end{array}$ & $169 \mathrm{ml}$ & $128.25 \mathrm{ml}$ & $115 \mathrm{ml}$ \\
\hline
\end{tabular}

\section{Characterization of standard group of patients as per present study protocol}

Authors recruited 50 patients and treated with placebo along with oxytocin, in that Gravida 1 (Primi) group patients were 20 and average blood loss was $325 \mathrm{ml}$,
Gravida 2 group patients were 20 and avg. blood loss was $248.5 \mathrm{ml}$ and Gravida 3 group patients were 10 and average blood loss was $205 \mathrm{ml}$.

Table 4: Standard group patient's characterization.

\begin{tabular}{|c|c|c|c|c|}
\hline $\begin{array}{l}\text { Treatment } \\
\text { given }\end{array}$ & $\begin{array}{l}\text { No. of } \\
\text { patients }\end{array}$ & Primi & ${ }_{2}$ Gravida & $\begin{array}{l}\text { Gravida } \\
3\end{array}$ \\
\hline $\begin{array}{l}\text { Placebo+ } \\
\text { oxytocin }\end{array}$ & 50 & 20 & 20 & 10 \\
\hline \multicolumn{2}{|c|}{ Average blood loss } & $325 \mathrm{ml}$ & $248.5 \mathrm{ml}$ & $205 \mathrm{ml}$ \\
\hline \multicolumn{2}{|c|}{ Standard deviation } & 78.63 & & \\
\hline
\end{tabular}

Standard deviation for standard group was 78.63 which was shown in Table 4.

Table 5: Blood loss details in both groups.

\begin{tabular}{|c|c|c|c|c|c|c|c|c|}
\hline \multicolumn{2}{|c|}{ Blood loss (ml) } & \multicolumn{2}{|c|}{ TXA } & \multirow[t]{2}{*}{ Total } & \multicolumn{3}{|c|}{ Placebo } & \multirow[t]{2}{*}{ Total } \\
\hline & Primi & G2 & G3 & & Primi & G2 & G3 & \\
\hline $1-100$ & 2 & 4 & 3 & 9 & 0 & 0 & 1 & 10 \\
\hline $101-200$ & 12 & 16 & 7 & 35 & 2 & 6 & 2 & 10 \\
\hline $201-300$ & 6 & 0 & 0 & 6 & 5 & 17 & 2 & 24 \\
\hline $301-400$ & 0 & 0 & 0 & 0 & 13 & 1 & 1 & 15 \\
\hline
\end{tabular}

In present study authors have taken first time pregnancy, second- and third-time pregnancy peoples as test group along with their blood loss by giving TXA as follows 9 patients were having blood loss in between 1-100ml, 35 patients were having blood loss in between 101-200ml, 6 patients were having blood loss in between $201-300 \mathrm{ml}$, no patients were having blood loss in between 301$400 \mathrm{ml}$. In standard group patients treated with placebo without TXA as follows one patient have blood loss in between $1-100 \mathrm{ml}, 10$ patients were having blood loss in between 101-200ml, 24 patients were having blood loss in between 201-300ml, 15patients were having blood loss in between $301-400 \mathrm{ml}$ which was shown in Table 5 . Finally, authors found that among both groups very less mean blood loss in test group patients i.e. treated with TXA is $141.9 \mathrm{ml}$ compared to standard group patients treated with placebo $270.4 \mathrm{ml}$, both groups standard deviation and P-value was shown in Table 6.

Table 6: Over all statistics in present study.

\begin{tabular}{|l|l|l|l|} 
Group & $\begin{array}{l}\text { Mean } \\
\text { blood loss }\end{array}$ & $\begin{array}{l}\text { Standard } \\
\text { deviation }\end{array}$ & P-value \\
\hline TXA & 141.9 & 44.27 & 0.03 \\
\hline Placebo & 270.4 & 78.63 & 0.18 \\
\hline
\end{tabular}

\section{DISCUSSION}

In present study authors recruited 100 pregnant patients based on inclusion and exclusion criteria. Out of 100 patients, 50 patients were considered to be of one group and another 50 patients to the other group. TXA was given to one group and Placebo was given to the other group. The amount of blood loss was measured for both groups.

In present study, out of 100 patients $16(16 \%)$ patients were from the age group of 15-20 years, 65 (65\%) patients from the age group of 20-25 years and 19 (19\%) patients from the age group of 25-30 years. The maximum deliveries take place between the age group of 20-25years as the age increases occurrence of deliveries decreases.

In present study, out of 100 patients, in the placebo group $9(18 \%)$ patients were having the blood loss ranges from $1-100 \mathrm{ml}, 35(70 \%)$ patients were having the blood loss ranges from $101-200 \mathrm{ml}, 6(12 \%)$ patients were having the blood loss ranges from $201-300 \mathrm{ml}, 0(0 \%)$ patients were having the blood loss ranges from $301-400 \mathrm{ml}$.

In the TXA group $1(2 \%)$ patient was having the blood loss ranges from $1-100 \mathrm{ml}, 10(20 \%)$ patients were having the blood loss ranges from $201-300 \mathrm{ml}, 24(48 \%)$ patients were having the blood loss ranges from 301-400ml, 15 (30\%) patients were having the blood loss ranges from 401-500ml. This indicates that TXA group patients had less amount of blood loss when compared to placebo group, supported by Chunbo Li et al, MD et al, Ducloybouthors et al and Gungorduk et. al. ${ }^{10-12}$ 
In present study, out of 100 patients in placebo group $31(62 \%)$ were normal vaginal delivery (NVD) patients, $10(20 \%)$ were NVD with episiotomy patients and 9 (18\%) were abnormal labour with forceps. In TXA group $34(68 \%)$ were normal vaginal delivery (NVD) patients, $15(30 \%)$ were NVD with episiotomy patients and $1(2 \%)$ was abnormal labour with forceps.

This indicates that patients who undergone NVD with episiotomy and abnormal labour with forceps had more amount of blood loss than normal vaginal delivery patients.

In present study, out of 100 patients $50(100 \%)$ patients were given placebo and the average blood loss was found to be 270.4. A $50(100 \%)$ patients were given TXA and the average blood loss was found to be 141.9.

This indicates that TXA is the effective drug than placebo in reducing blood loss by measuring blood supported by Novikova N et al, Loic Sentilhes et al, Sanyu Research unit et al and William Ng et. al, Gohel Mayur et al. ${ }^{13-17}$

In present study out of 100 patients $50(100 \%)$ patients were given with placebo, the overall statistical results were found to be 270.4 (mean), standard. deviation found to be 78.6 , and p-value is 0.18 which is not significant. In present study out of 100 patients $50(100 \%)$ patients were given with TXA, the overall statistical results were found to be 141.9 (mean), std. deviation found to be 44.2, and $\mathrm{p}$-value is 0.03 which indicates that the results are significant.

Tranexamic acid given group patients have less amount of blood loss than the placebo group. The blood loss measured in TXA group is half of the amount of blood loss of placebo group.

\section{CONCLUSION}

Post-partum haemorrhage is the leading cause of maternal deaths, so there is an obvious need for additional treatments and interventions. Worldwide PPH is the second leading cause of deaths.

So additional treatment like tranexamic acid is necessary to prevent mortality rate.

In present study authors conclude that use of tranexamic acid prophylactically, can prevent the $\mathrm{PPH}$ by reducing the blood loss.

For PPH condition general drugs like oxytocin gives the result of blood loss approximately to $300 \mathrm{ml}$.

But TXA gives the result approximately to $150 \mathrm{ml}$. Present study concluded that Tranexamic acid (TXA), is a promising agent for both prevention and treatment of post-partum haemorrhage.

\section{ACKNOWLEDGMENTS}

Authors would like to thank Pharmacy practice staff of PRRMCP and Gynecology Department in RIMS.

Funding: No funding sources

Conflict of interest: None declared

Ethical approval: The study was approved by the Institutional Ethics Committee

\section{REFERENCES}

1. L. Sentilhes. Tranexamic acid for the prevention and treatment of post-partum haemorrhage. BJA 2015; 114 (4): 576-87.

2. Anderson J, Etches D, Smith D. Postpartum haemorrhage. In: Damos JR, Eisinger SH, eds. Advanced Life Supportin Obstetrics (ALSO) provider course manual.Kansas: American Academy of Family Physicians, 2000;1-15.

3. Rouse DJ, Leindecker S, Landon M, Bloom SL, Varner MW, Moawad AH, et al. The MFMU Cesarean Registry: uterine atony after primary cesarean delivery. Am J Obstetr Gynecol. 2005;193(3):1056-60.

4. Magann EF, Evans S, Hutchinson M, Collins R, Howard BC, Morrison JC. Postpartum hemorrhage after vaginal birth: an analysis of risk factors. S Med J2005;98:419-22.

5. Weeks AD, Mirembe FM. The retained placenta new insights into an old problem. Eur J Obstet Gynecol Reprod Biol. 2002;102:109-10.

6. Tara V Shanbhag; Pharmacology; 2nd edition; Elseveir.361-3.

7. K.D. Tripathi; essentials of Medical Pharmacology; 7th edition; Jaypee; 189-94,331-2.

8. Joseph $\mathrm{T}$ Dipiro. American Hospital formulary Services; 2nd edition; Lippincott Williams and WIllkins; 560.

9. Shobha Misra. Randomized double blind placebo control studies, the "Gold Standard" in intervention based studies. Indian J Sex Transm Dis AIDS. 2012; 33(2): 131-4.

10. Chunbo Li, Yuping Gong, Lingling Dong MD, Bingying Xie MD, Zhiyuan Dai MD. Is prophylactic tranexamic acid administration effective and safe for postpartum hemorrhage prevention? 2016; 96:1.

11. Gungorduk K, Asıcıoğlu O, Yildırım G, Ark C, Tekirdağ Aİ, Besımoglu B. Can intravenous injection of tranexamic acid be used in routine practice with active management of the third stage of labor in vaginal delivery? A randomized controlled study. Am J Perinatol. 2013;30(05):407-14.

12. Ducloy-Bouthors AS, Jude B, Duhamel A, Broisin F, Huissoud C, Keita-Meyer $\mathrm{H}$, et al. High-dose tranexamic acid reduces blood loss in postpartum haemorrhage. Critical Care. 2011;15(2):R117.

13. Novikova N, Hofmeyr GJ, Cluver C. Tranexamic acid for preventing postpartum haemorrhage. Cochrane Database of Systematic Reviews. 2015(6). 
14. Loïc Sentilhes. Tranexamic acid for preventing postpartum hemorrhage after vaginal delivery: a multicenter randomized, double-blind, placebocontrolled trial J. 2009;34-39.

15. Esen UI. Re: The prevention and treatment of postpartum haemorrhage: what do we know, and where do we go next?. BJOG: Inter J Obstetr Gynaecol. 2015;122(8):1145-6.

16. Ng WC, Jerath A, Wasowicz M. Tranexamic acid: a clinical review. Anaesthesiol Intensive therapy. 2015;47(4):339-50.

17. Mayur G, 1 Purvi P, Ashoo G, Pankaj D, Efficacy of tranexamic acid in decreasing blood loss during and after cesarean section: A randomized case controlled prospective study. J Obstet Gynecol India. 2007;5(3):227-30.

Cite this article as: Parveen S, Chandra GK, Reddy KR, Sree AVK, Varalakshmi M, Gayathri R, et al. A comparative study on placebo and trenaxamic acid for the prophylaxis is of post-partum hemorrhage:a randomised double-blind control study. Int J Reprod Contracept Obstet Gynecol 2019;8:1143-8. 